\title{
EVALUASI TEPAT PASIEN, TEPAT OBAT, DAN TEPAT DOSIS PENGGUNAAN ANTIPSIKOTIK PASIEN SKIZOFRENIA DI RUMAH SAKIT JIWA PROVINSI NTB
}

\author{
Ni Komang Wijiani Yanti*, Dwi Andayani \\ Fakultas Kesehatan Universitas Nahdatul Ulama, NTB \\ *:wijiani16@gmail.com
}

\begin{abstract}
ABSTRAK
Salah satu gangguan jiwa yang disebabkan oleh ketidakmampuan individu dalam melakukan penyesuaian diri adalah gangguan jiwa skizofrenia. Skizofrenia adalah gangguan kronis dan parah yang memengaruhi cara seseorang berpikir, merasakan, dan bertindak. Penatalaksanaan pengobatan skizofrenia salah satunya menggunakan antipsikotik. Parameter evaluasi meliputi tepat obat, tepat dosis, tepat pasien, dan tepat frekuensi penggunaan obat. Penelitian ini merupakan penelitian deskriptif dengan metode analisis deskriptif dengan pengumpulan data dilakukan secara retrospektif. Pengumpulan data dilakukan dengan metode purposive sampling dengan melihat data rekam medik kesehatan pasien skizofrenia rawat inap periode Januari - Desember 2019 sebanyak 87 data rekam medik. Dari sampel penelitian, skizofrenia lebih banyak dialami oleh laki - laki $(79.31 \%)$ dan berusia 26-35 tahun (56.32\%). Tipe skizofrenia yang paling banyak diderita adalah tipe paranoid sebanyak 75 pasien (86.21\%).Gambaran penggunaan antipsikotik terbanyak adalah golongan kombinasi antipsikotik tipikal + atipikal sebanyak 44 pasien $(50.57 \%)$. Hasil evaluasi ketepatan penggunaan antipsikotik diperoleh $88.51 \%$ tepat obat; $100 \%$ tepat pasien; $98.85 \%$ tepat dosis; dan $96.55 \% \%$ tepat frekuensi. Penggunaan obat selama pasien dirawat inap sudah baik, namun diperlukan evaluasi dan monitoring karena masih terdapat ketidaktepatan obat, dosis, dan frekuensi pada penggunaan obat antipsikotik.
\end{abstract}

Kata Kunci: Skizofrenia, Antipsikotik, Penggunaan Obat, Evaluasi.

\begin{abstract}
One of the mental disorders caused by the inability of individuals to make adjustments is schizophrenia. Schizophrenia is a chronic and severe disorder that affects the way a person thinks, feels, and acts. The management of schizophrenia treatment one of which uses antipsychotics. Evaluation parameters include the right drug, right dose, right patient, and right frequency of drug use. This research is a descriptive research with descriptive method with data collection done retrospectively. Data collection was carried out by using purposive sampling method by looking at the medical record data of inpatient schizophrenia in the period of January - December 2019 as many as 87 medical records. From the research sample, schizophrenia was more experienced by men $(79.31 \%)$ and aged 26-35 years (56.32\%). The most common type of schizophrenia is paranoid type as many as 75 patients (86.21\%). The most common use of antipsychotics is the typical + atypical antipsychotic combination group of 44 patients $(50.57 \%)$. The results of evaluating the accuracy of the use of antipsychotics obtained $88.51 \%$ right of the
\end{abstract}


drug; $100 \%$ right patient; $98.85 \%$ correct dosage; and $96.55 \% \%$ exact frequency. The use of drugs during hospitalization is good, but evaluation and monitoring are needed because there are still inaccuracies in the drug, dosage, and frequency in the use of antipsychotic drugs.

Keywords: schizophrenia, antipsychotics, drug use, evaluation.

\section{PENDAHULUAN}

Salah satu gangguan jiwa yang disebabkan oleh ketidakmampuan individu dalam melakukan penyesuaian diri adalah gangguan jiwa skizofrenia. Menurut National Institute of Mental Health, skizofrenia adalah gangguan kronis dan parah yang mempengaruhi cara seseorang berpikir, merasakan, dan bertindak. Meskipun skizofrenia tidak umum seperti gangguan mental lainnya, ini bisa sangat melumpuhkan. Sekitar 7 atau 8 orang dari 1.000 akan menderita skizofrenia seumur hidup mereka. Skizofrenia adalah gangguan mental yang parah, ditandai dengan gangguan dalam berpikir, berbicara, persepsi, dan bersosialisasi. Skizofrenia termasuk pengalaman psikotik, seperti mendengar suara atau delusi, dan dapat menghilangkan kemampuan dalam hal pekerjaan dan pendidikan ${ }^{1}$.

Skizofrenia mempengaruhi lebih dari 21 juta orang di dunia, pada laki- laki 12 juta dan perempuan 9 juta ${ }^{1}$. Data Riset Kesehatan Dasar tahun 2018 mencatat jumlah penderita skizofrenia di Indonesia sebanyak $0,67 \%$ per 1.000 orang, sedangkan untuk wilayah Nusa Tenggara Barat telah tercatat jumlah pravelensi penderita skizofrenia sebanyak $0,959 \%$ per 1.000 orang $^{2}$.

Gangguan skizofrenia pada umumnya ditandai oleh distorsi pikiran oleh efek yang tidak serasi atau tumpul ${ }^{3}$. Gejala penyakit skizofrenia bervariasi pada setiap orang dan dapat berubah dari waktu ke waktu yang bisa semakin membaik atau semakin memburuk. Gejala dari skizofrenia meliputi halusinasi (terutama mendengar suara-suara), delusi, tidak dapat mengambil keputusan, tidak dapat berekspresi, tidak memiliki pendirian yang tetap atau labil, tidak kooperatif, tidak dapat merawat diri, tidur dan nafsu makan terganggu. Gejala skizofrenia 
dibagi menjadi tiga kategori: gejala positif, gejala negatif, dan gejala kognitif ${ }^{4}$. Gejala positif ditandai dengan halusinasi, delusi, dan bicara dan perilaku yang tidak teratur. Gejala negatif pada pasien skizofrenia ditandai dengan penurunan fungsi sosial dan emosional, ekspresi, cara bicara, kemauan melaksanakan aktifitas sosial $^{5}$. Gejala kognitif skizofrenia ditandai dengan adanya gangguan dalam hal konsentrasi, kecepatan berfikir, kurangnya fokus, dan penyelesaian masalah ${ }^{6}$.

Penatalaksanaan pengobatan skizofrenia salah satunya menggunakan Antipsikotik. Antipsikotik merupakan terapi obatobatan pertama yang efektif mengobati skizofrenia ${ }^{7}$. Pengobatan dengan obat antipsikotik diindikasikan untuk hampir semua episode psikosis akut pada pasien dengan skizofenia. Penggolongan

\section{METODE PENELITIAN}

Penelitian ini merupakan penelitian observasional dengan rancangan penelitian cross sectional dan pendekatan secara retrospektif. Pengumpulan data dilakukan secara retrospektif yaitu meninjau kembali antipsikotik ada dua, yaitu antipsikotik tipikal dan antipsikotik atipikal. Perbedaan dari dua golongan tersebut ada pada pengaruh efek samping yang ditimbulkan.

Penggunaan antipsikotik yang tidak sesuai dengan ketentuan seperti tidak tepat pasien, tidak tepat pemberian obat, dan tidak tepat dalam pemberian dosis sering kali dijumpai dalam pelaksanaan praktik sehari-hari di pusat kesehatan. Ketidaktepatan dalam pemilihan obat, tidak tepat dalam pemilihan pasien, serta tidak tepat dosis akan menjadi kegagalan terapi pengobatan pada skizofrenia. Dari pemaparan tersebut, penelitian ini dilakukan untuk mengetahui ketepatan antipsikotik pada pasien, ketepatan penggunaan obat, dan ketepatan dosis pada pasien skizofrenia rawat inap di Rumah Sakit Jiwa Mutiara Sukma Provinsi NTB.

pola terapi pasien skizofrenia dengan melihat data rekam medik kesehatan pasien skizofrenia rawat inap Rumah Sakit Jiwa Mutiara Sukma Provinsi NTB Tahun 2019,

Populasi penelitian adalah seluruh pasien dengan diagnosis skizofrenia 
di Rumah Sakit Jiwa Mutiara Sukma Provinsi NTB Tahun 2019 sebanyak 705 orang.

Teknik pengambilan sampel pada penelitian ini dilakukan secara non probability sampling yakni purposive sampling, yaitu teknik penentuan sampel dengan pertimbangan tertentu ${ }^{8}$.

Analisis data yang dilakukan adalah dengan menganalisis keterkaitan data klinik, data laboratorium dan tujuan terapi skizofrenia kemudian data diolah menggunakan Microsoft Excel dan disajikan dalam bentuk table, presentase dan diagram.

\section{HASIL DAN PEMBAHASAN}

\section{A. Karakteristik Pasien Berdasarkan Jenis Kelamin}

Hasil penelitian dengan menggunakan 87 catatan medik mendapatkan jumlah pasien berjenis kelamin laki-laki sebanyak 79,31\% dan pasien dengan jenis kelamin perempuan sebanyak 20,69\%. Karakteristik pasien skizofrenia berdasarkan jenis kelamin dapat dilihat dalam tabel 1.
Tabel 1. Data Karakteristik pasienskizofrenia dengan penggunaan antipsikotik

\begin{tabular}{|l|l|l|l|}
\hline No & $\begin{array}{l}\text { Jenis } \\
\text { Kelamin }\end{array}$ & $\begin{array}{l}\text { Jumlah } \\
\text { Pasien }\end{array}$ & $\begin{array}{l}\text { Persentase } \\
(\boldsymbol{\%})\end{array}$ \\
\hline 1 & Laki-laki & 69 & 79,31 \\
\hline 2 & Perempuan & 18 & 20,69 \\
\hline Jumlah & $\mathbf{8 7}$ & $\mathbf{1 0 0}$ \\
\hline
\end{tabular}

Persentase yang didapat pada penelitian ini yang berdasarkan karakteristik pasien skizofrenia berdasarkan jenis kelamin menunjukkan perbedaan yang signifikan. Pasien dengan jenis kelamin laki-laki lebih banyak menderita skizofrenia dibandingkan dengan perempuan, hal ini disebabkan karena pengaruh antidopaminergik estrogen yang dimiliki oleh wanita.

Estrogen memiliki efek pada aktivitas dopamine di nukleus akumben dengan cara menghambat pelepasan dopamin. Penyebab dari etiologi terjadinya skizofrenia dikarenakan peningkatan jumlah reseptor dopamine di nukleus kaudatus, akumben, dan putamen ${ }^{9}$.

\section{B. Karakteristik Pasien Berdasarkan Usia}

Data hasil penelitian yang dikumpulkan dengan melihat karakteristik pasien berdasarkan usia 
pasien skizofrenia diketahui terbanyak pada rentang usia 26-35 tahun dengan nilai persentase $56,32 \%$ dengan jumlah 49 pasien pasien. Karakteristik pasien berdasarkan usia selengkapnya dapat dilihat pada tabel 2

Tabel 2. Data Karakteristik pasien skizofrenia berdasarkan usia denganpenggunaan antipsikot Pada rentang usia 26-35 skizofrenia

\begin{tabular}{|l|l|l|l|}
\hline No. & Usia & JumlahPasien & $\begin{array}{l}\text { Persentase } \\
(\boldsymbol{\%})\end{array}$ \\
\hline 1 & $18-25$ & 13 & 14,94 \\
\hline 2 & $26-35$ & 49 & 56,32 \\
\hline 3 & $36-45$ & 17 & 19,54 \\
\hline 4 & $46-55$ & 6 & 6,90 \\
\hline 5 & $56-65$ & 2 & 2,30 \\
\hline \multicolumn{2}{|l}{ Jumlah } & $\mathbf{8 7}$ & $\mathbf{1 0 0}$ \\
\hline
\end{tabular}

terjadi pada akhir masa remaja atau dewasa awal dan jarang terjadi sebelum masa remaja atau setelah usia 40 tahun, hal ini dikarenakan rentang usia tersebut merupakan usia produktif yang dipenuhi dengan banyaknya faktor pencetus stress ${ }^{9}$. Biasanya faktor pencetus stres diantaranya mencakup masalah dengan keluarga maupun teman kerja, pekerjaan yang terlalu berat, hingga masalah ekonomi yang dapat mempengaruhi perkembangan emosional.. Stres dapat menyebabkan terjadinya peningkatan sekresi neurotransmitter glutamat (senyawa prekursor GABA) pada sistem limbik sehingga menyebabkan terjadinya ketidakseimbangan neurotransmitter. Ketidakseimbangan neurotransmitter glutamat itu sendiri dapat mencetuskan terjadinya skizofrenia ${ }^{9}$.

\section{Karakteristik Pasien Berdasarkan Tipe Klinis Skizofrenia \\ Data penelitian yang berdasarkan} tipe klinis ditentukan dari diagnosa yang diberikan dokter kepada pasien skizofrenia dengan penggunaan antipsikotik rawat inap. Tipe klinis skizofrenia yang paling banyak adalah tipe klinis skizofrenia paranoid, yaitu sebanyak 75 pasien dengan nilai persentase $86,21 \%$.

Pada data rekam medik untuk pasien skizofrenia didapatkan bahwa pasien dengan tipe klinis yang paling banyak yaitu skizofrenia dengan tipe paranoid. Dalam penelitiannya ${ }^{10}$. menyatakan penyakit skizofrenia paranoid merupakan tipe skizofrenia yang sering dijumpai dinegara manapun. Skizofrenia dengan tipe paranoid biasanya memiliki gejala yang paling menonjol adalah delusi dan halusinasi, mendengar suara- 
suara, dan mudah marah atau tak bisa mengontrol emosinya.

Tabel 3. Pasien berdasarkan tipe klinis skizofrenia

\begin{tabular}{|c|c|c|c|c|}
\hline No & Tipe & Kode & $\begin{array}{c}\text { Jumlah } \\
\text { pasien }\end{array}$ & $\begin{array}{c}\text { Persen } \\
\text { tase } \\
(\%)\end{array}$ \\
\hline 1 & $\begin{array}{c}\text { Skizofrenia } \\
\text { Paranoid }\end{array}$ & F20.0 & 75 & 86,21 \\
\hline 2 & $\begin{array}{l}\text { Skizofrenia } \\
\text { Hebrefenik }\end{array}$ & F20.1 & 3 & 3,45 \\
\hline 3 & $\begin{array}{c}\text { Skizofrenia } \\
\text { Katatonik }\end{array}$ & F20.2 & 1 & 1,15 \\
\hline 4 & $\begin{array}{c}\text { Skizofrenia } \\
\text { Yang Tak } \\
\text { Terinci }\end{array}$ & F20.3 & 8 & 9,20 \\
\hline \multicolumn{3}{|c|}{ Jumlah } & 87 & 100 \\
\hline
\end{tabular}

Tipe skizofrenia yang terbanyak kedua setelah tipe paranoid adalah skizofrenia dengan tipe klinis skizofrenia yang tak terinci sebanyak 8 pasien dengan nilai persentase 9,20\%. skizofrenia dengan tipe klinis skizofrenia yang tak terinci ditandai dengan memenuhi kriteria gejala skizofrenia pada umumnya namun tidak memenuhi kriteria untuk skizofreia paranoid, hebrefenik, katatonik, dan residual. Pasien dengan tipe klinis skizofrenia yang tak terinci menunjukkan gejala bicara kacau, menyendiri, kadang keluyuran, tertawa, dan bicara sendiri, mengamuk.
Tipe skizofrenia ketiga terbanyak adalah skizofrenia dengan tipe hebrefenik sebanyak 3 pasien dengan nilai persentase $3,45 \%$ dan tipe yang sedikit ditemukan adalah pasien skizofrenia dengan tipe katatonik sebanyak 1 pasien dengan jumlah persentase $1,15 \%$.

\section{Gambaran Penggunaan Obat Antipsikotik pada pasien Skizofreni}

Pengobatan yang digunakan Pasien Skizofrenia.

Pada tabel 4 menunjukkan penggunaan obat pada pasien skizofrenia rawat inap di Rumah Sakit Jiwa Mutiara Sukma Provinsi NTB dengan pasien sebanyak 87 pada periode Januari Desember 2019. Berdasarkan tabel diatas, penggunaan terapi yang diterima oleh pasien skizofrenia di Rumah Sakit Jiwa Mutiara Sukma Provinsi NTB lebih banyak penggunaan antipsikotik yang merupakan evaluasi utama dari penelitian ini dan pada setiap peresepan diikuti oleh pemberian obat lain yang menyesuaikan dengan kondisi pasien. 
Tabel 4. Pengobatan yang banyak digunakan pada pasien skizofrenia

\begin{tabular}{|c|c|c|c|c|c|}
\hline \multirow{2}{*}{ No } & \multirow{2}{*}{ Kategori terapi } & \multirow{2}{*}{ Golongan } & Nama Obat & $\mathbf{n}$ & $\mathbf{( \% )}$ \\
\hline \multirow{3}{*}{1} & \multirow{3}{*}{ Antipsikotik } & \multirow{2}{*}{ Tipikal } & Haloperidol & 19 & 21,84 \\
\cline { 4 - 6 } & & Chlorpromazin & 18 & 20,69 \\
\cline { 4 - 6 } & & \multirow{2}{*}{ Atipikal } & Trifluoperazin & 7 & 8,05 \\
\cline { 4 - 6 } & & & Risperidon & 61 & 70,11 \\
\hline \multirow{2}{*}{2} & Antikolinergik & & Clozapin & 27 & 31,03 \\
\hline
\end{tabular}

Penelitian ini mengevaluasi penggunaan antipsikotik pada pasien skizofrenia rawat inap di RSJ Mutiara Sukma Provinsi NTB dengan menggunakan catatan rekam medik pasien sebanyak 87 periode Januari Desember 2019 yang meliputi parameter tepat obat, tepat pasien, tepat dosis, serta tepat frekuensi.

1. Penggolongan Antipsikotik

Tabel 5. Penggolongan antipsikotik

\begin{tabular}{|c|c|c|c|}
\hline No & $\begin{array}{c}\text { Golongan } \\
\text { Obat } \\
\text { Antipsikotik }\end{array}$ & $\begin{array}{c}\text { Jumlah } \\
\text { Pasien }\end{array}$ & Persentase \% \\
\hline 1 & $\begin{array}{c}\text { Antipsikotik } \\
\text { Tipikal }\end{array}$ & 12 & 13,79 \\
\hline 2 & $\begin{array}{c}\text { Antipsikotik } \\
\text { Atipikal }\end{array}$ & 31 & 35,63 \\
\hline 3 & Kombinasi & 44 & 50,57 \\
\hline \multicolumn{2}{|c|}{ Jumlah } & $\mathbf{8 7}$ & $\mathbf{1 0 0}$ \\
\hline
\end{tabular}

Antipsikotik yang banyak digunakan pada pasien skizofrenia rawat inapdi rumah sakit jiwa Mutiara Sukma adalah antipsikotik dengan kombinasi tipikal dengan atipikal penggunaannya sebanyak 44 pasien dengan nilai persentase $50.57 \%$. Penggunaan secara kombinasi antara atipikal dengan tipikal paling banyak diberikan karena antipsikotik tipikal mampu memperbaiki gejala positif dari skizofrenia, namun secara umum tidak dapat memperbaiki gejala negatif. Sedangkan antipsikotik atipikal mampu memperbaiki gejala negatif dan positif dan lebih efektif mengobati pada pasien yang resistensi ${ }^{9}$.

E. Evaluasi Penggunaan Antipsikotik Pasien Skizofrenia

1. Tepat Obat

Tabel 6. Data Tepat Obat

\begin{tabular}{|c|c|c|c|}
\hline $\begin{array}{c}\text { N } \\
\text { o. }\end{array}$ & $\begin{array}{c}\text { Ketepatan } \\
\text { Obat }\end{array}$ & $\begin{array}{c}\text { Jumlah } \\
\text { Pasien }\end{array}$ & $\begin{array}{c}\text { Persen } \\
\text { tase } \\
(\mathbf{\%})\end{array}$ \\
\hline 1 & Tepat Obat & 77 & 88,51 \\
\hline 2 & $\begin{array}{c}\text { Ketidaktepatan } \\
\text { Obat }\end{array}$ & 10 & 11,49 \\
\hline \multicolumn{2}{|c|}{ Jumlah } & $\mathbf{8 7}$ & $\mathbf{1 0 0 , 0 0}$ \\
\hline
\end{tabular}


Pada hasil evaluasi dari penggunaan antipsikotik kategori tepat obat ditemukan ketepatan obat pada penggunaannya sebanyak 77 pasien dan ketidaktepatan obat yang dilihat berdasarkan penggunaan serta adanya potensi interaksi obat sebanyak 10 pasien. Potensi interaksi obat yang timbul karena adanya penggunaan antipsikotik kombinasi antara haloperidol dengan chlorpromazine yang bersifat serius karena mekanisme yang terjadi ketika haloperidol dengan chlorpromazine dikombinasikan keduanya dapat meningkatkan interval QTc. Interval QTc merupakan manisfestasi masa potensial aksi memanjang dengan terjadinya depolarisasi yang meyebabkan denyutan prematur dan takikardi polimorfik ${ }^{10}$.

\section{Tepat Pasien}

Dari hasil analisis dengan kategori tepat pasien pada 87 catatan data rekam medik pasien skizofrenia rawat inap bahwa 100\% memenuhi kriteria dari tepat pasien. Seperti yang tertera pada tabel 7

Dari hasil analisis tersebut tidak ditemukan pasien dengan riwayat penyakit berat atau tertentu serta pasien dengan kondisi hamil

Tabel 7. Data Tepat Pasien

\begin{tabular}{|c|c|c|c|}
\hline No & $\begin{array}{c}\text { Ketepatan } \\
\text { pasien }\end{array}$ & $\begin{array}{c}\text { Jumlah } \\
\text { Pasien }\end{array}$ & $\begin{array}{c}\text { Persentase } \\
(\mathbf{\%})\end{array}$ \\
\hline 1 & $\begin{array}{c}\text { Ketepatan } \\
\text { Pasien }\end{array}$ & 87 & 100 \\
\hline 2 & $\begin{array}{c}\text { Ketidaktepatan } \\
\text { Pasien }\end{array}$ & 0 & 0 \\
\hline \multicolumn{2}{|c|}{ Jumlah } & $\mathbf{8 7}$ & $\mathbf{1 0 0}$ \\
\hline
\end{tabular}

. Dari keseluruhan kasus pasien dengan diagnosa skizofrenia yang diberikan antipsikotik sudah sesuai dengan kondisi pasien atau tidak adanya kontraindikasi. Data tersebut dievaluasi menggunakan standar British National Formulary 54 tahun 2008 dan Drug Information Handbook 17" edition.

3. Tepat Dosis

Ketepatan terapi pada pasien skizofrenia dilihat dari ketepatan pemberian dosis. Dosis obat antipsikotik dimulai dari diberinya dosis rendah lalu perlahan-lahan dinaikkan, dapat juga langsung diberi dosis tinggi, sesuai dengan keadaan pasien dan kemungkinan timbuknya efek samping ${ }^{11}$. Pada evalausi ketepatan dosis ini diukur menggunakan standar terapi dari Drug Information Handbook edisi 17" evaluasi ketepatan dosis 
penggunaan antipsikotik pada pasien rawat inap sebanyak 87 pasien dapat dilihat pada tabel 8 .

Tabel 8. $\begin{aligned} & \text { Ketepatan } \\
& \text { antipsikotik }\end{aligned}$
\begin{tabular}{|l|l|l|l|}
\hline No & $\begin{array}{l}\text { Ketepatan } \\
\text { Dosis }\end{array}$ & $\begin{array}{l}\text { Jumlah } \\
\text { Pasien }\end{array}$ & $\begin{array}{l}\text { Persentase } \\
(\%)\end{array}$ \\
\hline 1 & Tepat Dosis & 86 & 98,85 \\
\hline 2 & $\begin{array}{l}\text { Tidak Tepat } \\
\text { Dosis }\end{array}$ & 1 & $1,15 \%$ \\
\hline Jumlah & $\mathbf{8 7}$ & $\mathbf{1 0 0 , 0 0}$ \\
\hline
\end{tabular}

Seperti yang terlihat pada

Tabel 8. ketepatan dosis pada pasien skizofrenia suda baik dengan jumlah pasien sebanyak 86 dengan nilai persentase $98.85 \%$ yang mendapatkan terapi antipsikotik sudah tepat pemberian dosis dan ketidaktepatan penggunaan dosis sebanyak pasien dengan nilai persentase $1.15 \%$.

4. Tepat Frekuensi

\section{Tabel 9. Tepat Frekuensi}

\begin{tabular}{|c|c|c|c|}
\hline No & $\begin{array}{c}\text { Ketepatan } \\
\text { Frekuensi }\end{array}$ & $\begin{array}{c}\text { Jumlah } \\
\text { Pasien }\end{array}$ & Persentase \\
\hline 1 & Tepat Frekuensi & 84 & 96,55 \\
\hline 2 & $\begin{array}{c}\text { Ketidaktepatan } \\
\text { Frekuensi }\end{array}$ & 3 & 3,45 \\
\hline \multicolumn{2}{|c|}{ Jumlah } & $\mathbf{8 7}$ & $\mathbf{1 0 0 . 0 0}$ \\
\hline
\end{tabular}

Dari 87 catatan medik ditemukan juga ketidaktepatan frekuensi pemberian antipsikotik pada pasien skizofrenia. Tepat frekuensi merupakan pemakaian yang telah ditentukan perharinya ${ }^{10}$. Semakin besar ketidaktepatan frekuensi yang diberikan semakin besar pula ketidak patuhan pasien dalam mengkonsumsi obat. Pada hasil evaluasi ketepatan frekuensi di 87 catatan rekam medik pasien skizofrenia rawat inap didapat 3 pasien yang mengalami ketidaktepatan frekuensi pemberian antipsikotik. Frekuensi obat dinyatakan tidak tepat apabila aturan yang diberikan ada yang lebih dan ada yang kurang dari yang dianjurkan dalam acuan standar Drug Information Handbook $17^{\text {th }}$ Edition

\section{KESIMPULAN}

Dari hasil evaluasi pada penelitian ini dapat disimpulkan bahwa ketepatan penggunaan antipsikotik pasien skizofrenia rawat inap di Rumah Sakit Jiwa Mutiara Sukma Provinsi NTB periode JanuariDesember 2019 sudah baik dalam penggunaan antipsikotik. Maka dapat diambil kesimpulan sebagai berikut: hasil evaluasi ketepatan penggunaan antipsikotik diperoleh $88,51 \%$ tepat obat; $100 \%$ tepat pasien; $98,85 \%$ tepat dosis; dan $96,55 \%$ tepat frekuensi.

\section{UCAPAN TERIMA KASIH}

Terimakasih disampaikan kepada semua pihak yang telah membantu 
terlaksananya penelitian ini.

Terimakasih kami sampaikan seluruh pihak Universitas Nahdlatul Ulama

NTB dan Direktorat Riset dan

Pengabdian Masyarakat Direktorat

Jenderal Riset dan Pengembangan

Kementerian Riset, Teknologi, dan

Pendidikan Tinggi.

\section{DAFTAR PUSTAKA}

1. World Health Organization (WHO).

2019.https://www.who.int/newsroom/factsheets/detail/schizophrenia Di akses tanggal 20 Maret 2020

2. Kemenkes RI. 2018, Riset Kesehatan Dasar; RISKESDAS. Jakarta: Balitbang Kemenkes RI.

3. Ibrahim, A.S. 2011, Skizofrenia Spliting Personality. Tanggerang; Jelajah Nusa

4. Wells, B. G., Joseph T. Dipiro., Terry L. S., and Cecily P. D., 2015, Pharmacotherapy Handbook 9th Edition. New York: McGraw-Hill Education.

5. Hanson, E. K, H., Daniel W. 2010. Assesment of Pharmacotherapy for Negative Symptoms of Schizophrenia. 2010. 563-571 p.

6. Chisholm-Burns, M. A. et al., 2013, Pharmacotherapy Principles \& Practice Fourth Edition. New York: McGraw-Hill Education.

7. Irwan, M., Fajriansyah, A., Sinuhaji, B., Indrayana, M. 2008. Penatalaksanaan Skizofrenia. Riau; Fakultas Kedokteran Universitas Riau
8. Sugiyono, 2018. Metode Penelitian Kuantitatif, Kualitatif, dan $R \& D$. Bandung; Alfabeta

9. Yulianty, Mawar Dwi, dkk. 2017. Studi Penggunaan Antipsikotik dan Efek Samping pada Pasien Skizofrenia di Rumah Sakit Jiwa Sambang Lihum Kalimantan Selatan. Program Studi Farmasi Universitas Lambung Mangkurat. Sumatra Barat

10. Fadilla A.R., dan Puspitasari R.M., 2015, Evaluasi Ketepatan Penggunaan Antipsikotik Pada Pasien Skizofrenia Rawat Inap, Sainstech Farma Vol.9 No.1.

11. Maharani, Liza. 2004. Kajian Penggunaan Obat Antipsikosispada Pasien Skizofrenia Diunit Rawat Inap Rumah Sakit Grhasia Propinsi Daerah Istimewa Yogyakarta Periode Januari-Desember 2003I. Fak.Farmasi. Universitas Sanata Darma. Yogyakarta. 